Pamiętnik Literacki 2020, 4, s. 149-157

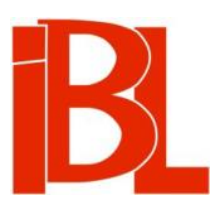

Nieznane listy Henryka Sienkiewicza do

Stanisława Witkiewicza - świadectwa

przyjaźni i świadkowie szczęścia

Oprac. Agnieszka Kuniczuk-Trzcinowicz 
Pamiętnik Literacki CXI, 2020, z. 4, PL ISSN 0031-0514

DOI: $10.18318 / \mathrm{pl} .2020 .4 .11$

\title{
NIEZNANE LISTY HENRYKA SIENKIEWICZA DO STANISŁAWA WITKIEWICZA - ŚWIADECTWA PRZYJAŹNI I ŚWIADKOWIE SZCZĘŚCIA
}

\author{
Opracowała \\ AGNIESZKA KUNICZUK-TRZCINOWICZ Uniwersytet Warszawski
}

\section{O dotychczas znanym oraz nowym zbiorze korespondencji}

W edycji korespondencji Henryka Sienkiewicza zostało opublikowanych 38 listów pisarza do Stanisława Witkiewicza $z$ lat 1880-1903ㄹ. W latach osiemdziesiątych XIX stulecia przyjaźń między Witkiewiczem a Sienkiewiczem była szczególnie silna, obaj mężczyźni nie doświadczyli jeszcze najbardziej traumatycznych momentów życia, stąd w korespondencji często pojawia się ton rozbawienia, żartów a nawet frywolności. Witkiewicz zajmował poczesne miejsce w prywatnych relacjach Sienkiewicza, był świadkiem narodzin największej miłości pisarza, można powiedzieć, iż w początkowym okresie znajomości Marii Szetkiewiczówny i Sienkiewicza przyjął funkcję swego rodzaju pośrednika między młodymi zakochanymi. $\mathrm{Z}$ tonu korespondencji jasno wynika, że pierwsza pani Sienkiewiczowa również darzyła Witkiewicza ogromną sympatią, w pełni odwzajemnianą.

Czytając ten cały zespół listów Sienkiewicza do Witkiewicza, stajemy się świadkami podejmowania ważnych wyborów życiowych przez autora Szkiców węglem - decyzji o włączeniu się do redakcji „Słowa”, pisaniu kolejnych utworów i, co bardzo interesujące, o ich autocenzurowaniu. Mocno nacechowane emocjonalnie informacje o rozkwitającym uczuciu do Szetkiewiczówny, zabieganie o zgodę na ślub oraz „kronika” szczęśliwych dni małżeńskich to główne tematy korespondencji adresowanej do Witkiewicza. Dowiadujemy się także o oczekiwaniu na pierworodne dziecko i o pierwszych miesiącach życia z potomkiem w rodzinie. Można uznać, że pomimo ewidentnego nadużywania - przez Sienkiewicza - kreacji słownej listy do Witkiewicza są jednymi $z$ najbardziej szczerych i spontanicznych spośród całej jego korespondencji, zarówno z tego, jak i z późniejszych okresów. Stosowane zabiegi językowe wyglądają raczej na zabawę, a nie tworzenie rzeczywistości, co pojawi się później np. w listach do Jadwigi Janczewskiej. Stosunkowo mało znajdujemy też wiadomości suchych, pozbawionych emocji, służących wyłącznie przekazywaniu faktów z aktualnego życia pisarza. Taki informacyjno-sprawozdawczy ton mają listy do osób bardzo bliskich Sienkiewiczowi, które jednak nie uczestniczyły w szczególny sposób w jego zabawach językowych. Wśród tych odbiorców są z pewnością: Helena Sienkiewiczówna - siostra Henryka; Maria Babska - cioteczna siostrzenica, czyli ostatnia żona, oraz jego teściowa Wanda Szetkiewiczowa.

Pozyskane przez Zakład Narodowy im. Ossolińskich w 2018 roku cztery nie publikowane dotąd listy Sienkiewicza do Witkiewicza stanowią ciekawe uzupełnienie tej znanej już

1 H. Sienkiewicz, Listy. T. 5, cz. 2. Oprac., wstęp, przypisy M. Bokszczanin. Warszawa 2009. 
korespondencji. Wszystkie napisane zostały w Warszawie, dwa wysłano do Monachium, po jednym do Meranu i na warszawską ulicę Hożą. Jednocześnie wśród listów i skompletowanych z nimi kopert zaadresowanych do Stanisława Witkiewicza znajduje się jedna koperta bez zawartości, adresowana do niego, do Meranu. Jeśli się szczegółowo przejrzy zgromadzoną w zbiorach Ossolineum korespondencję Sienkiewicza, owa koperta właśnie zaczyna być największą zagadką.

Pierwszy z prezentowanych tutaj listów nie został skatalogowany w Archiwum Henryka Sienkiewicza jako list do Witkiewicza. Nie posiada nagłówka, zapisanej daty, w treści listu nie pojawiają się imię i nazwisko odbiorcy, dlatego znalazł się wśród korespondencji zatytułowanej: „do nieznanych adresatów”. Wnikliwa analiza treści listu pozwala sądzić, iż był on skierowany do Witkiewicza. Nie wszystkie przytoczone argumenty mają tę samą wagę, wolno jednak domniemywać, że trzy mocno przemawiają za potraktowaniem Witkiewicza jako adresata. Trzeci wydaje się dyskusyjny. Wszystkie można ułożyć w następujące sekwencje:

1. Nie rozpoznany wcześniej list rozpoczyna się zdaniem: „Nie miałem wiadomości od Ciebie dość dawno, więc myślę, że Cię oczy bolą". Choroba oczu była tematem opublikowanych wcześniej listów do Witkiewicza z 2 oraz 22 I 1881: „Z jakiego powodu panują w Meranie choroby oczu?”, „Jak Ty się masz z oczami?”2, co pokazuje, iż wypowiedź wprowadzająca nie jest tutaj użyta przypadkowo. W kolejnym zdaniu prezentowanego listu pisarz informuje, że posyła przyjacielowi numery „Kłosów” oraz „Niwy”, zwyczaj ten zainicjował z początkiem tego samego roku, w liście z 7 I wysłał je pierwszy raz, a w korespondencji z 19 I czytamy: „Wczoraj wieczór [...] posłałem "Kłosy“ i "Niwę»"3. Warto zwrócić uwagę na zastosowany przez Sienkiewicza czas gramatyczny. Autor Szkiców węglem wyraźnie zaznacza wykonywanie czynności „tu i teraz”, jasno informuje też o tym, co zrobił wcześniej. Jeśli przyjmiemy, że list prezentowany w tym artykule jako pierwszy napisał Sienkiewicz do Witkiewicza, możemy roboczo datować go na $18 \mathrm{I}$, ponieważ zawarte w obu listach informacje uzupełniają się.

2. Pojawiający się motyw sztuki, którą „lada moment” będą wystawiać w teatrze ${ }^{4}$, jest w styczniu 1881 jednym z głównych tematów korespondencji między Sienkiewiczem a Witkiewiczem, od jej premiery bowiem zależał wyjazd Sienkiewicza za granicę, gdzie miał on spotkać nie tylko Witkiewicza, ale także swoją przyszłą żonę, Szetkiewiczównę.

3. Najbardziej wymowna zaś i mogąca przeważyć szalę na stronę potwierdzenia domniemanego adresata i daty powstania listu jest kwestia rozstrojonych nerwów i pełnego obaw tonu, który przebija w całym liście. Autor nie informuje, co spowodowało jego złe samopoczucie, ewidentnie jednak daje do zrozumienia, iż to raczej „choroba” duszy, a nie ciała: ,jeśli dusza ludzka ma swoje przypływy i odpływy, to jestem w chwili takiego odpływu, jak dawno nie pamiętam. Zdaje mi się, że w końcu wszystko mnie zawiedzie”. W liście pisanym prawdopodobnie następnego dnia, tuż po przeczytaniu listu od Witkiewicza, ton niepokoju ustępuje, o czym autor Starego sługi mówi słowami:

Wczoraj wieczór wrzuciłem list do skrzynki, dziś rano odebrałem Twój, więc piszę drugi. [...] Dziękuję Ci za tę parę słów, bom po nich spokojniejszy. Czy panna Maria zdrowa już i czy nie ma śladów tego zaziębienia, o którym wspominasz? ${ }^{5}$

Sienkiewicz na początku 1881 roku był przed zaręczynami z Szetkiewiczówną, na ślub

2 H. Si en ki ew i c z: list do S. Witkiewicza, z 2 I 1881; list do S. Witkiewicza, z 22 I 1881. W: Listy, s. 249, 263.

3 H. Sienkiewicz, list do S. Witkiewicza, z 19 I 1881. W: jw., s. 259.

4 Chodzi o wystawienie dramatu H. Sienkiewicza Na jedna kartę. Warszawska premiera odbyła się 24 II 1881 w teatrze Rozmaitości.

5 Sienkiewicz, list do Witkiewicza, z 19 I 1881, s. 259. 
$\mathrm{z}$ nią dostał pozwolenie przyszłych teściów dopiero w tym samym roku w maju. Zatem potwierdzanie uczuć wybranki, konieczność kontaktowania się $z$ nią za pośrednictwem Witkiewicza były jego codziennością. We wcześniejszych listach Sienkiewicz daje adresatowi także do zrozumienia, iż korespondencję $z$ nim traktuje jako miejsce do zwierzeń dotyczących własnych uczuć do Szetkiewiczówny, ale przede wszystkim wymianę intelektualną z Witkiewiczem, który ewidentnie stanowił dla autora Szkiców węglem partnera do rozmów na tematy związane $z$ literaturą i sztuką. Taka też sugestia znajduje się $\mathrm{w}$ prezentowanym liście: „Daruj mi, że wspominam Ci o moich dolegliwościach. Nie zawsze jestem [taki], ale przynajmniej do Ciebie nie chciałbym pisywać konwencjonalnie".

4. Zagadkę stanowią przywołane w publikowanym tu liście „obrazki polowe z 63 r[oku]”, w tym czasie bowiem nie zajmował się Sienkiewicz niczym o tej problematyce (właściwie tylko późniejsze opowiadanie We mgle ${ }^{6}$ można by przyporządkować do tematyki związanej $\mathrm{z}$ powstaniem styczniowym, ale trudno ten tekst traktować jako więcej niż jeden obrazek). W liście z 18 VIII 1881 (zatem późniejszym) pojawia się prośba pisarza do malarza dotycząca tej samej sprawy: „Nie rysuj Jamioła, a natomiast weź jakie płótno i na poczekaniu, bez modelów kropnij bitewkę lub bitwę, lub podjazd z 63 r[oku]"7. To zagadnienie będzie wymagało dłuższych badań i filologicznych dociekań, dziś bowiem nie wiadomo, o jakie utwory Sienkiewicza może chodzić.

Gdyby wszystkie $z$ hipotez uznać za trafne, to ostatnim zabiegiem stałoby się połączenie pustej koperty adresowanej do Meranu, wysłanej z Warszawy 18 I, z listem, którego adnotację „do nieznanego adresata” zmieniono by na „list do Stanisława Witkiewicza, Warszawa, 18 stycznia 1881" - co też w prezentowanej tu korespondencji uczyniono. Decyzję taka podjęto na mocy przytoczonych argumentów. Oględziny papieru listowego i koperty dopełniają ową decyzję, gdyż - podobnie jak w innych przypadkach - zauważono, że papier i koperta stanowią komplet $\mathrm{z}$ tego samego zestawu papeterii.

Drugi z zamieszczonych listów kontynuuje stale pojawiający się w listach do Witkiewicza temat sprzedaży obrazów, ponieważ Sienkiewicz sprawował funkcję nieformalnego, ale mocno zaangażowanego Witkiewiczowskiego marchanda. List został napisany już po tym, gdy Ludwik Górski - zafascynowany malarstwem Witkiewicza - kupił od Sienkiewicza obraz zatytułowany Kanion. Wspomniany fragment korespondencji przynosi także informacje na temat planowanej pracy Sienkiewicza w redakcji „Słowa”.

Przywołany list dotyczy tych samych spraw, które przewijają się w korespondencji już opublikowanej, wydaje się więc konieczne, aby wprowadzić go do jej porządku. W tym miejscu pojawia się kwestia sporna i konieczność skorygowania datowania listów. Po przeliczeniu daty tego drukowanego wcześniej i opatrzonego numerem 27 należy poprawić jego datę podaną w starym stylu. Widniejąca na stemplu pocztowym data: „Warszawa, 24 okt[ober] 1881”, powinna zostać przeliczona w nowym stylu jako 5 XI 1881. Pomyłkę spowodował zapewne dopisek Sienkiewicza w nagłówku listu: „poniedziałek wieczór”; 24 X (stary styl) był właśnie poniedziałek, po przeliczeniu natomiast poniedziałek wypadał 7 XI. Trzeba więc odnotować, że list 27 wyszedł spod pióra Sienkiewicza dwa dni wcześniej, a prezentowany tu - nie publikowany dotąd, $z$ datą na pieczęci 26 X 1881 (stary styl, środa) powstał właśnie 7 XI (nowy styl). Zatem w strukturze wydrukowanej już korespondencji miałby swoje miejsce między listem 27 a 28. $Z$ treści wszystkich trzech listów wynika, iż Górski kupił (lub zamierzał nabyć) niejeden obraz Witkiewicza. To powoduje, że skupiając się wyłącznie na

$6 \quad$ Kwestia związana $\mathrm{z}$ napisaniem opowiadania We mgle pojawia się w korespondencji zarówno Sienkiewicza, jak i Marii Dembowskiej z Jadwigą Janczewską pod koniec lat osiemdziesiątych (1889), a więc później niż cytowane tu wzmianki o „obrazkach” z roku 1863. Ostatecznie utwór We mgle został opublikowany dopiero w 1908 roku.

7 H. Sienkiewicz, list do S. Witkiewicza, z 18 VIII 1881. W: Listy, s. 283. 
treści, mamy wrażenie, iż list 28 został napisany przed prezentowanym tu, po raz pierwszy publikowanym.

W trzecim liście potwierdza Sienkiewicz swoją fascynację Afryką. Utrzymuje całość korespondencji w stylistyce językowej naśladującej tamtejsze nazewnictwo, pojawiają się także informacje dotyczące książek, które poszerzają wiedzę pisarza o tym kontynencie. W dwóch listach, pisanych już po ślubie $z$ Szetkiewiczówną, energia witalna Sienkiewicza i radość z aktualnej sytuacji życiowej odzwierciedlona może zostać w tytule jego planowanej i niestety nie zrealizowanej powieści: Kronika szczęścia.

Czwarty list to krótka prośba o spotkanie w sprawach, jak można sądzić, zrozumiałych dla Witkiewicza. Zwrot „potrzebuję rozmawiać o bawołach” dla niewtajemniczonego czytelnika wydaje się dość zagadkowo sformułowany, ale dla Witkiewicza, zaprzyjaźnionego z rodziną Sienkiewiczów i będącego z nią w stałym kontakcie, zapewne nie stanowił zagadki. List został zaniesiony prawdopodobnie przez posłańca, często bowiem Sienkiewicz korzystał z tej formy komunikacji z osobami, które znajdowały się - tak jak on - w Warszawie. Nie jest datowany, koperty nie opatrzono stemplem pocztowym. Aby podać choć w przybliżeniu okres powstania listu, należy wziąć pod uwagę kilka zmiennych. Po pierwsze, nie mogło to być wcześniej niż 16 VIII 1881, gdyż treść listu wskazuje na to, że Maria i Henryk Sienkiewiczowie mieszkają razem, więc są po ślubie. Do roku 1883 mieszkali prawie bez przerwy w Warszawie, potem Maria poważniej zachorowała, a zatem małżonkowie niemal cały czas spędzali w uzdrowiskach. Witkiewicz natomiast zaczął mieszkać w Warszawie przy Hożej mniej więcej w połowie 1882 roku i był to jego adres do roku 1890, gdy malarz z rodziną wyjechał do Zakopanego. Nakładając na siebie te dwa porządki, możemy stwierdzić, że terminus ad quem będzie stanowił rok 1882, za datę końcową zaś uznamy schyłek roku 1883.

W publikowanych tu listach ustalono czas ich powstawania, powołując się na zapisy Sienkiewicza oraz stemple pocztowe widniejące na kopertach, które $z$ racji tego, że stanowią we wszystkich przypadkach komplety z papeterii, uznano za prawidłowo dopasowane. Listy ułożono chronologicznie (sugerując także ich miejsce w ogólnej strukturze znanej korespondencji między Sienkiewiczem a Witkiewiczem), trzeci (niedatowany) opublikowany jest jako ostatni, ale w wyniku dedukowania, w którym roku mógł zostać napisany, uzgodniono, że jeśli ten przedział czasowy okazałby się prawdziwy, to i tak list byłby czwarty z kolei. Pierwszy $\mathrm{z}$ listów ma swoje miejsce w ogólnej strukturze drukowanej dotąd korespondencji między listem 10 a 11, drugi wszedłby między listy 26 a 27. List trzeci powinien się znaleźć między listem 33 a 34, natomiast niedatowany list ostatni - po liście oznaczonym jako 36.

Słowa niemożliwe do odczytania zasygnalizowano [-], wielokrotność wyrazów [--]. Ortografię i interpunkcje dostosowano do współczesnych norm, np. „bronzy” - „brązy”; „Napisz mi czy odebrałeś [...]” - „Napisz mi, czy odebrałeś [...]”.

Zabiegami modernizacyjnymi objęto też pisownię: yję/ję (np. „koncesyję”/,koncesje”, „pensyję”/ „pensję), yć/eć („dojrzyć”/ „dojrzeć”), pozostawiono natomiast słowa charakterystyczne dla stylu wypowiedzi Sienkiewicza: „przygotowywa”, „poczem”.

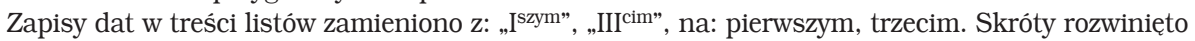
w nawiasach kwadratowych, np.: „guld[enów]”.

Wprowadzono także kursywy do tytułów utworów literackich i zwrotów łacińskich oraz cudzysłowy do tytułów gazet. Zwroty grzecznościowe zapisano - konsekwentnie - wielkimi literami. Podkreślone przez Sienkiewicza linią ciagłą wyrazy wyróżniono rozstrzelonym drukiem.

Zbiór prezentowanych tu listów przechowywany jest w Zakładzie Narodowym im. Ossolińskich w Archiwum Henryka Sienkiewicza pod nazwą: Korespondencja Henryka Sienkiewicza 1882-1913 (sygn. 202/18), i wydrukowany zostaje po raz pierwszy. 


\section{Listy Henryka Sienkiewicza do Stanisława Witkiewicza}

[Warszawa, 18 stycznia 1881]

Nie miałem wiadomości o Tobie dość dawno, więc myślę, że Cię oczy bolą. Pomimo tego posyłam „Kłosy” i „Niwę”. Jeśli nie możesz teraz czytać, przeczytasz, jak wyzdrowiejesz. U mnie nic nowego. Próbuję pisać obrazki polowe z [18]63 i tak mnie to absorbuje, że nie robię nic innego. Nawet $\& \&^{1}$ śpią od niejakiego czasu. Pragnę, by rzecz była cenzuralna - czy się uda, nie wiem. Rzecz to jest dosyć trudna w ogóle, bo trzeba umieć godzić epizodyczność z kompozycją w ten sposób, by jej epizodami nie przeciażyć. Trzeba także unikać utarty[ch] kolei[n] sentymentalizmu i szowinizmu. Myślę jednak, że się z trudności wywiążę, choć lepiej bym to zrobił, gdybym osobiście był spokojniejszy. O sztuce zawsze nic nie wiem, a przynajmniej wiem tylko termin przybliżony. Jak mnie $\mathrm{z}$ tym trzymają na łańcuchu, to sam tylko jeden wiem. Trudno!

Od kilku dni nerwy moje straszliwie są rozstrojone, a jeśli dusza ludzka ma swoje przypływy i odpływy, to jestem w chwili takiego odpływu, jak dawno nie pamiętam. Zdaje mi się, że w końcu wszystko mnie zawiedzie. Gdybym wiedział, że jutro się nie obudzę, wybrałbym może prędzej to niż co innego.

Zidiociałem do tego stopnia, że mam złe przeczucia i [-] obawę. W tym miłym stanie trwam od dni kilku.

U Twoich pañ ${ }^{2}$ nie byłem już od dziesięciu dni, ale teraz taki jestem rozdrażniony, że wizyta moja nie zrobiłaby im przyjemności. Rankami bazgrzę. Od dziś wracam znowu do \&\& i ten list piszę z redakcji. Miłe życie, w którym są tylko różnego rodzaju \&\& i nic więcej. Jako cel, jako samo dla siebie, już to wzniosłe.

Napisz mi, czy odebrałeś pierwszy zeszyt „Niwy”. Jeśli nie, to Ci przyślę drugi egzemplarz. Daruj mi, że wspominam Ci o moich dolegliwościach. Nie zawsze jestem [taki], ale przynajmniej do Ciebie nie chciałbym pisywać konwencjonalnie.

O nowym Hamlecie - nie myślę w tej chwili. Na to trzeba więcej spokoju. Również i Kronika szczęścia poszła ad acta, bo to muszą być rzeczy pisane przedmiotowo i w zupełnym zebraniu umysłu.

W ogóle można by więcej robić i lepiej, gdyby nie ucisk, jakiego doznaje się od wszelkiego rodzaju niepewności i wewnętrznych, i zewnętrznych.

Z tym wszystkim, jeśli nie podrę tego, com napisał, i jeśli cenzura puści, to się ukaże niedługo.

\section{Henryk Sienkiewicz}

Papier listowy (po złożeniu $13 \times 21 \mathrm{~cm}$ ) i pusta koperta są $\mathrm{z}$ tej samej papeterii. Pusta koperta, zaadresowana: „Austria Süd Tirol Meran / Monsieur Stanislas Witkiewicz”. Stempel pocztowy: „6 Janw[ar] 1881, Warszawa”, powtórzony na kopercie dwa razy.

Chodzi o felietony dla „Słowa”, które Sienkiewicz podpisywał pseudonimem \&\&.

Prawdopodobnie chodzi o niezamężne siostry Witkiewicza, czyli o Marię (Mary) i Eugenię Witkiewiczówny. 
Kochany Stachu!

[Warszawa, 7 listopada 1881]

Powinno Cię było już dojść drugie 300 rs $^{1}$. Czy doszło? Co do 500 guld[enów] nie widziałem od paru dni Górskiego ${ }^{2}$, nie wiem, czy wyłuszczy je zaraz, czy po przyjściu obrazu. Wolałbym, gdyby zaraz. Owidzkiego ${ }^{3}$ dotąd nie ma. Pewno chędoży. Latarnika albo już odebrałeś, albo odbierzesz zaraz ${ }^{4}$. Mówiąc między nami, jest podły - ale tu się podoba. Przyszłość jest ciemna - o ile jednak można coś w niej dojrzeć prawdopodobnie od nowego roku zostaję redaktorem wielkiego dziennika ${ }^{5}$. Czterech tutejszych literatów pożycza 25000 rs od pieniężników alias „dobrych bogaczy” i kupuje koncesje „Słowa”. Ci czterej są Breza, Lubowski, Wrotnowski i Antałek Zaleski ${ }^{6}$. Chca wprawdzie, bym i ja należał do pożyczki, ale nie mnie brać! Mówię: chcecie, bym był redaktorem - będę - ale do wydawnictwa nie przystępuję. Dacie mi pensję 1200 rs i od wiersza osobno - będa zyski, bierzcie, będą straty - płaczcie. $\mathrm{Ci}$, uczyniwszy mi wymówki, godzą się. Prawda, że mądrze. Nie chcę nic ryzykować, prócz pracy, choć szanse są. Tymczasem w „Wieku” i w „Echu” taki jest popłoch, tyle intryg i wściekłości, że sobie nie wyobrazisz ${ }^{7}$. Cóż mnie to może uczynić! Kazio Zalewski ofiarował współpracę ${ }^{8}$. Rzekłem: „Z tym parchem nie pójdę”. Myślę, że podbieram im prenumeratorów, czego jeśli nie uczynię, to jestem arabskim ziarnkiem bobu. Jeśli zaś jeszcze nie przyjdzie nic do skutku, będę równie kontent, jak jestem. Pana Boga! Czasu jest mało. Gdybym wyszedł na Nowy Rok, wypadnie mi wystapić na pierwsze numery, z powieścią ${ }^{9}$. Pewno zrobię coś historycznego, bo najłatwiej. Będziesz pisywał z Monachium o sztuce ${ }^{10}$. Ale to Ci powiem, że gdybym mógł się stąd wydostać i pojechać z Maryjanką ${ }^{11}$ do Włoch, byłbym najszczęśliwszy ${ }^{12}$. Podłość ciemności, wilgoć i flakowatość tutejszej aury przeszła wszelkie granice imaginacji. Teraz jest godzina pierwsza i prawie nie mogę pisać, tak ciemno.

Naprawdę to lubię tylko jedną czynność: palić w piecach. Na czerwonej ścianie i na brązach są od tego boskie połyski. Marynia nie oddaje sprawiedliwości memu paleniu, ale zreszta jest boska i zdrowa, jak nigdy nie była. Była u nas Twoja kobieta $^{13}$. Moja idzie do niej z wizytą. Ściskam Cię

\section{Henryk}

Papier listowy z wytłoczonym monogramem „MS” i koroną; koperta i papier (po złożeniu 11,5 × $18 \mathrm{~cm}$ ) stanowią komplet. Koperta zaadresowana: „Bayern München / Schwanthalten Str[asse] 36.II.links / Monsieur Stanislas Witkiewicz”. Stemple pocztowe: „Warszawa, 26 Oct[ober] 1881” (starego stylu), „München, 10 Nov[ember]”.

1 Skrót „rs” - rubel srebrny.

2 Zapewne chodzi o Ludwika Górskiego (1818-1908), jednego z założycieli „Słowa”, bliskiego znajomego Sienkiewicza. Był bratem Konstantego Górskiego, przyjaciela pisarza. Obaj Górscy mieli z nim częste kontakty, znali też obrazy Witkiewicza (Sienkiewicz trzymał je u siebie w mieszkaniu). Z listu opublikowanego wcześniej, gdzie wspomniany został prawdopodobnie ten sam obraz, wynika, że nosił on tytuł Kanion. Informacja na temat tego, który z Górskich ostatecznie kupił szkic, nie jest do końca pewna.

3 Jan Felicjan Owidzki (1852-1913) - współpracownik Witkiewicza w tygodniku „Wędrowiec”. W liście z 29 X 1880 można przeczytać, że miał bliski kontakt z malarzem. Przypuszczalnie Sienkiewicz czekał na Owidzkiego, by dowiedzieć się czegoś bliższego o przyjacielu.

$4 \quad$ Latarnik wyszedł w druku pod koniec 1881 roku. 
5 U schyłku roku 1881 działacze i dziennikarze warszawscy utworzyli dziennik o nastawieniu liberalno-konserwatywnym, noszący tytuł „Słowo”. Sienkiewiczowi przypadła rola redaktora. Pismo oficjalnie zostało zatwierdzone w styczniu 1882. Sienkiewicz był redaktorem do 1887 roku, a dziennik funkcjonował do 1919 roku.

6 Adam Breza (1850-1936), Edward Lubowski (1837-1923), Antoni Wrotnowski (18471902), Antoni Zale ski (1858-1895) - założyciele „Słowa”.

7 „Wiek” - gazeta warszawska, której redaktorem od roku 1875 do 1901 był Kazimierz Zalewski. „Echo” - dziennik, w latach 1877-1881 redagowany przez Zygmunta Sarneckiego. W roku 1881 redaktorem „Echa” został Jan Noskowski, który wkrótce połączył je ze „Słowem”.

8 Prawdopodobnie mowa tu o Kazimierzu Zalewskim (1849-1919), krytyku, współredaktorze „Nowin” i „Wieku”. Nisko cenionym przez Sienkiewicza.

9 W pierwszym roku działalności „Słowa” Sienkiewicz opublikował następujące własne utwory literackie: Wspomnienie z Maripozy, Bartek Zwycięzca oraz Z puszczy Białowieskiej.

10 Wizje Sienkiewicza wypełniły się dopiero, gdy Witkiewicz zaczął publikować artykuły o sztuce w „Wędrowcu” pod redakcją Artura Gruszeckiego, a więc po roku 1884.

11 Tak Sienkiewicz nazywał swoją żonę.

12 Wszystko wskazuje na to, że w tym okresie jednak nie pojechali.

13 Prawdopodobnie chodzi o Marię Pietrzkiewiczównę (1853-1931), późniejszą żonę Witkiewicza.

Drogi M’Kunie! (nazwa z okolic Kongo)

[Warszawa,] 8 maja $1882^{1}$

Bóg Ci zapłać! Byłem pewny, że napisałem najostatniejszą podłotę. Dzięki jednak Marambie podoba się to w ogóle. Straciłem całkowicie zmysł do oceny własnych rzeczy i niech mnie Pangasowie sprzedadza jako niewolnika Fanom, a nawet M'Bosom, jeślim nie rozpaczał nad tym Bartkiem² od początku do końca. Tymczasem ze wszystkich stron mówią: furora! Lubowski bierze się za bok - nawet podobno Kazio $^{3}$ chwali. Obchodziłoby mnie to daleko więcej, gdyby umysł mój nie był w tej chwili całkowicie między Kongo, Ogowe ${ }^{4}$ i dorzeczami Baukory. Czytam w tej chwili Wnętrze Afryki Jacolliota rzecz dość nędz[n]a - trochę Verne'a ${ }^{5}$, ale marzę i marzę. Marynia nazywa się od niejakiego czasu M’Bwana. Ja zaś jestem znany w domu pod nazwą Yombi i należę stanowczo do pokolenia Fanów, którzy farbują sobie włosy na czerwono z pomoca wapna. „Słowo” w tej chwili obchodzi mnie tyle, co i Ciebie - a niewiele więcej czasu mi zajmuje. Chodzę tam między pierwszym a trzecim, robię numerację, rewizję - rzucam okiem, czy Antał [Zaleski] nie popełnił jakiejś podłości ultramontańskiej, słucham, jak sobie obaj z Breza przymawiają lekko od idiotów, złodziei, świń i obiecują po pysku - poczem wracam do M’Bwany, która przez ten czas przygotowywa obiad złożony z manioku, kaslawy ${ }^{6}$ i małp pieczonych oraz $z$ krokodylich jaj i ptastwa upolowanego w lasach mangrowiowych ${ }^{7}$. Jak Ty się masz? jak Twoje zdrowie? czy Ci się już pogoiły te wrzody pozostałe po ukąszeniach kuru-huru i rany otrzymane w walce $z$ gorylem?

Czemu nie przysyłasz Twoich malowanych fetyszów? Może udałoby mi się sprzedać je za piasek złoty Dulusfom lub Ehlizabom. A im później, tym trudniej, bo przed nadchodząca skwarną pora kryją się w gęstwiny lasów.

Kiedy się do nas wybierzesz? Korzenie manioku już kazałem wyciskać na Twoje przybycie. Teraz jest ciepło. Siadaj więc w swoja piroge - i przyjeżdżaj. 
Być może, że obecnie zajmę się czymś na wyrobek, co M'Gebethner i M'Wolff ${ }^{8}$ kupią za drogie pieniądze. Zresztą czas wrócić do Kronik i do Mieszanin ${ }^{9}$, choć wolałbym nie wiem co niż taką robotę, ale trzeba.

Piszże Ty trochę i o sobie. U nas wszystko dobrze. Moje Maryniątko zdrowe jak nigdy. W pierwszej połowie lipca spodziewamy się przyjścia na świat małego Gobbi ${ }^{10}$. Na wrzesień może ja gdzie wylecę leczyć się, bo nerwy mam rozstrojone i boli mnie czasem krzyż ${ }^{11}$. Rogoziński ${ }^{12}$ wyjeżdża w połowie maja. Przechodził straszne historie $\mathrm{z}$ powodu braku pieniędzy. Wydłubałem dla niego 1000 rs od Branickiego ${ }^{13}$ i Bloch ${ }^{14}$ już mi obiecał. W tych dniach ma się zgłosić. Rozenowi ${ }^{15}$ zapłacił 1500 rs za 10 akwareli z poematu Słowackiego o Emirze Rzewuskim. Dość to ładne. Żmurko namalował Nerona nad Agripida ${ }^{16}$. Zgoła podłe! Owidzki puścił nas w trąbę. Nie wiem, czy jest, czy go nie ma. - Przyjedź na koniec maja. Będziemy robili plany podróży. Gdy je robimy z Marynią - zawsze na współkę z Tobą.

Ściskam Cię, mój drogi. Maryś przysyła Ci uścisk dłoni. Nie ma jej w tej chwili w domu, bo dopisałaby się. Daj pyska, drogi Stachu

Hen

Papier listowy (po złożeniu 11,5 × $18 \mathrm{~cm}$ ) błękitno-szary, $\mathrm{z}$ wytłaczaną literą „S”, komplet z kopertą. Koperta zaadresowana: „Bayern München / Monsieur Stanislas Witkiewicz / Ramberg str[asse] I/III”. Stempel pocztowy: „27 IV 1882” (starego stylu), „Warszawa”.

1 Na pieczęci widnieje data: „27 apr[il] 1882” (stary styl), co po przeliczeniu daje 9 V 1882. Zatem Sienkiewicz wysłał list następnego dnia po napisaniu.

2 Chodzi o nowelę Bartek Zwycięzca, która ukazała się w pierwszej połowie maja 1882 równolegle w „Czasie” i „Słowie”. Poza Poznańskiem spotkała się z dużą aprobatą krytyki i czytelników.

3 To, być może, Kazimierz Zalewski, o którym była mowa wcześniej.

4 Rzeka w Gabonie i Kongo. Uchodzi do Zatoki Gwinejskiej.

5 Zob. H. Kules za, A. J a ni a k, Nowe sienkiewicziana w zbiorach rękopisów Zakładu Narodowego im. Ossolińskich. W zb.: Mówia zbiory. Wykłady ossolińskie 2019-2020. Red. T. S o kół. Wrocław 2020 [w druku], s. 123, przypis 100: „Prawdopodobnie chodzi o Louisa Jacolliota L'Afrique mystérieuse, opowiadania ukazujące się w latach 1877-1884, i o Jules'a Verne’a Aventures de trois Russes et de trois Anglais dans L'Afrique australe, wydane w 1871 roku. Oba utwory musiały być czytane w oryginale, bo tłumaczeń na język polski dokonano po 1882 roku”.

6 Być może, na zasadzie analogii z turecką baklawą, pisarz stworzył neologizm „kaslawa”, i połączył w nim istniejącą granulowaną mączkę $z$ bulw manioku - kassawę, właśnie $z$ baklawą.

7 Mowa prawdopodobnie o lasach mangrowych - namorzynowych, występujących na styku lądu i morza, najliczniej u wybrzeży Ameryki Południowej i Afryki, charakteryzujących się obfitością organizmów.

8 Gustaw Adolf Gebethner (1831-1901) i August Robert Wolff (1862-1918) - właściciele wydawnictwa i księgarni założonych w 1857 roku w Warszawie, w pałacu Potockich przy Krakowskim Przedmieściu. Wydawcy dzieł Sienkiewicza.

9 Kroniki tygodniowe oraz Mieszaniny artystyczne i literackie publikował Sienkiewicz w „Słowie”. Były to felietony i wypowiedzi komentujące aktualne wydarzenia społeczne, artystyczne i literackie. Pisarz nie przepadał za tą praca, ale wykonywał ją ze względów finansowych.

10 Henryk Józef Si e n ki e w i c z (1882-1959) - syn i pierwsze dziecko Henryka Sienkiewicza i Marii Sienkiewiczowej z Szetkiewiczów, urodził się 15 VII.

11 We wrześniu pojechał Sienkiewicz na dwa miesiące do Nałęczowa, zrobił też wycieczkę do Puszczy Białowieskiej.

12 Stefan Szolc-Rogoziński (1861-1896) - podróżnik po Afryce (organizator dwóch wypraw), badacz Kamerunu. Sienkiewicz był rzecznikiem wyprawy Rogozińskiego. Zob. Kronika warszawska. „Słowo” 1882, nr 5, z 7 I.

13 Chodzi najprawdopodobniej o Franciszka Ksawerego Branickiego (1816-1879), polskiego 
szlachcica, finansistę, kolekcjonera sztuki, mecenasa polskiej emigracji i publicystę. Wspierał on materialnie i organizacyjnie powstanie styczniowe.

14 Przypuszczalnie mowa tu o Janie Gotlibie Blochu (1836-1902), polskim bankierze i przedsiębiorcy.

15 Jan Rozen (1854-1936) - malarz, wykonał ilustracje m.in. do Dumy o Emirze Rzewuskim J. Słowackiego, ilustrował także Ogniem i mieczem Sienkiewicza.

16 Franciszek Ż mu r k o (1895-1910) - malarz. Sienkiewicz wspomina jego obraz zatytułowany Neron nad zwłokami Agrypiny. M. G a w a le w i c z napisał na temat tego obrazu szkic Śmierć Agrypiny. Notatka historyczna do obrazu Franciszka Żmurki (Warszawa 1882).

4

[Warszawa, między rokiem 1882 a 1883]

Sobota

Jestem chory na oczy i nie czytam, nie piszę - przyjdź. Potrzebuję mówić o bawołach. Mańcia nie dość reaguje walce.

Jesteś wielki

Nigdzie nie wychodzimy

Papier listowy w dużą kratkę (po złożeniu 10,2 × 17,5 cm), komplet z kopertą. Koperta zaadresowana: „Wielmożny Stanisław Witkiewicz / Hoża n[umer] 12, drugie piętro”.

Abstract

\title{
HENRYK SIENKIEWICZ'S UNKNOWN LETTERS TO STANISŁAW WITKIEWICZ: TESTIMONIES OF FRIENDSHIP AND WITNESSES TO HAPPINESS
}

\author{
Edited by \\ AGNIESZKA KUNICZUK-TRZCINOWICZ University of Warsaw \\ ORCID: 0000-0002-6305-7595
}

Research in Henryk Sienkiewicz's Archive has led to finding four unpublished to this day letters by the writer to his friend Stanisław Witkiewicz. The collection of letters come from the time when Sienkiewicz was unmarried, and include new pieces of information to the writer's studies. The author of the article scrutinises the new correspondence, settles its chronology, and includes the letters into the earlier collection published by Maria Bokszczanin. Edition of the letters with endnotes is a crucial element of this publication. 